agents by their devious routes appear to lead to deletions of genetic material with loss of the in-built controls of the normal cell. He foels that in time these processes can be elucidated with chemical precision to reveal the differences, on the cytogenetic and molecular levels, hetween normal and cancer cells. Chemical carcinogens have received most attention and there are contributions on the probable modes of action of the biological alkylating agents, the carcinogenic lactones, nitroso compounds, the aromatic amines, the polycyclic hydrocarbons and various natural and metallic substances other than the radioactive metals. Articles on the tumour-producing viruses stress the wide physical, chemical and biological differences among them and indicate that the mechanisms by which they act may be equally varied. The relevance of such investigations to cancer in man has acquired new importance from the recognition that a type of cancer of Africans (the Central African lymphoma, or Burkitt tumour) may well be caused by a virus. Other contributions deal with immunological factors in carcinogenesis and with radiation carcinogenesis.

\section{U.K. Courses in Nuclear Sciences, 1964-66}

The Science Department of the British Council has compiled List No. 8 (May 1964) of Nuclear Studies. The catalogue is primarily a guide for overseas students wishing to undertake specialized formal training in nuclear science in the United Kingdom. Only full-time courses, generally of one week or more in duration, are listed. Information provided includes notes on sach of the courses and the institution at which it is held and also the fee and qualifications required for participa. tion. While most of the postgraduate courses listed deal solely with nuclear science, there are a few more general courses with a substantial content of advanced nuclear science. A science or engineering degree is usually necessary for admission, and courses for non-graduates deal solely with nuclear science. The $L i s t$ has unavoidably appeared too late for application to be made for many of the courses for the academic year 1964-65. It serves, however, to direct enquiries about future courses to appropriate institutions in time for 1965-66. Copies of the List and further information can be obtained from the Science Department, the British Council, 59 New Oxford Street, London, W.C.1.

\section{Royal Statistical Society}

AT the annual general meeting of the Royal Statistical Society on June 17, Mr. S. P. Chambers was elected president for the ensuing year. Mr. B. P. Emmett, Miss S. V. Cunliffe and Dr. J. A. Heady were elected honorary secretaries and Mr. C. T. Saunders was re-elected honorary treasurer. Prof. G. E. P. Box, professor of statistics in the University of Wisconsin, was awarded the Society's Guy Medal in Silver.

\section{University News :}

Bristol

THe following appointments to lectureships have been announced: Dr. S. M. Anstis (psychology); Dr. A. P. Cox (physical chemistry); Dr. M. Flower (mathematics, with the Computer Unit); Dr. P. L. Goggin (inorganic chemistry); Dr. J. Malos (physies); D. H. Peregrine (applied mathematics); M. J. R. Shave (mathematics, with the Computer Unit).

East Anglia

DR. S. F. Mason, reader in chemistry at the University of Exeter, has been appointed professor of chemistry in the School of Chemical Sciences.

Leeds

DR. H. L. PrICE, senior lecturer in mathematics, has been appointed as professor of mathematics. The following appointments to lectureships have been made: Dr. H. Hassall (biochemistry); T. F. Preece (agricultural botany); Dr. G. H. Smith (agricultural chemistry).

\section{Southampton}

Prof. Kenneth Mather, professor of genetics in the University of Birmingham since 1948 and Pro-ViceChancellor and Vice-Principal since 1960, has been appointed to succeed Dr. D. G. James on his retirement from the office of Vice-Chancellor of the University at the end of the session 1964-65. He was born in 1911 and was educated at Nantwich and Acton Grammar School and the University of Manchester. From 1934 until 1937 he was a lecturer in the Galton Laboratory in University College, London, and during 1937 and 1938 he was a Rockefeller Research Fellow at the California Institute of Technology and Harvard University. From 1938 until 1948 Prof. Mather was head of the Department of Genetics at the John Innes Horticultural Institution. He was a member of the Agricultural Research Council from 1949 until 1954 and from 1955 until 1960.

\section{Announcements}

Prof. Erwin Chargaff, professor of biochemistry in Columbia University, New York, has been awarded the 1963 Charles Léopold Mayer Prize of the Paris Academy of Sciences, for his work on nucleic acids.

Mr. A. Herzka, director of Pressurized Packaging Consultants, Ltd., London, has been elected president of the Society of Cosmetic Chemists of Great Britain for 1964-65.

The third European regional conference on "Electron Microscopy" will be held in Prague during August 26September 3. Further information can be obtained from the Organizing Committee, Third European Regional Conference on Electron Microscopy, Albertov 4, Prague 2.

A CONFERENCE on "Recent Advances in Activation Analysis" will be held at the University of Glasgow during August 27-28. Further information can be obtained from Dr. J. M. A. Lenihan, 9-13 West Graham Street, Glasgow, C.4.

A symposrum on "High-Energy Flectrons", organized by the European Association of Radiology, will be held in Montreux during September 7-10. Further information can be obtained from Dr. P. L. Cova, Casa di Cura S. Ambrogio, Via Faravalli 16, Milan.

THE ninth international conference on "Low Temperature Physics", sponsored by the International Union of Pure and Applied. Physics, the Ohio State University and the Battelle Memorial Institute, will be held in Columbus during August 31-September 4. Further information can be obtained from Dr. J. G. Daunt, Department of Physics, Ohio State University, Columbus, Ohio.

AN international conference on "Microwaves Circuit Theory and Information Theory" will be held in Tokyo during September 7-11. The programme will include sessions on: microwave theory and techniquos and electron devices; microwave antennæ and propagation; microwave communication systems; circuit theory; information theory. Further information can be obtained from Dr. K. Morita, c/o The Institute of Electrical Communication Engineers of Japan, 2-8 Fujimicho, Chiyodaku, Tokyo.

ErRata. In the communication entitled "Enolase and Fluorophosphate" by Sir Rudolph Peters, M. Shorthouse and L. R. Murray, which appeared on p. 1331 of the June 27 issue of Nature, for hydrolase in line 6 read hydratase; Table 1, lines 7 and 8 , for $\mathrm{FPO}_{3}^{-}$read $\mathrm{FPO}_{3}^{-}$; line 2 of the final paragraph, for $\mathrm{K}_{2} \mathrm{PO}_{3}$ read $\mathrm{K}_{2} \mathrm{~F} \cdot \mathrm{PO}_{3}$; in ref. 4, for Ochos read Ochoa. 